\title{
BENARKAH SELF ESTEEM MEMPENGARUHI PRESTASI AKADEMIK?
}

\author{
Satrio Budi Wibowo \\ Fakultas Psikologi, Universitas Muhammadiyah Metro, Jl. Ki Hajar Dewantara No. 116 \\ Iringmulyo Metro \\ satrio.budi.wibowo@mail.ugm.ac.id
}

\begin{abstract}
Self-esteem determines a person's overall mental development, it can even affect human behavior. The debate arose when researchers try to explain, whether student achievement is influenced by self-esteem? The author conducted a meta-analysis studies in attempt to clarify the relationship between the variables of self-esteem with academic achievement variable. This research analyzed over sixteen research journals, in which there are 29 studies that examine a relationship between self-esteem and academic achievement. Fifteen research journal use Global Self-esteem scale of the artificial factor in measuring the Rosenberg self-esteem, and research journals using the scale of the Tennessee Self-Concept Scale (TSCS). Academic achievement in 16 research journals obtained, operationalized as the average value of the end of the previous school year students and test scores of students in certain subjects. The analysis showed that there is a significant correlation between self-esteem with academic achievement. The correlation coefficient obtained population is low, amounting to 0,199 . The weak correlation coefficient can not be concluded that self-esteem does not affect academic achievement. However, there are two alternatives that could explain the lack of connection between self-esteem with academic achievement. First, the relationship between self-esteem with academic achievement is a two-way relationship. Second, the relationship between self-esteem with academic achievement associated with academic self-efficacy variables.
\end{abstract}

Keywords: academic achievement, self-esteem, the meta-analysis

\begin{abstract}
Abstrak
Self esteem menentukan perkembangan mental seseorang secara keseluruhan, bahkan dapat mempengaruhi prilaku manusia. Perdebatan muncul ketika menjelaskan, apakah prestasi akademik siswa dipengaruhi oleh self esteem. Penelitian ini menggunakan pendekatan meta analisis sebagai upaya memperjelas keterkaitan antara variabel Self esteem dengan variabel prestasi akademik. Lebih dari 16 jurnal penelitian yang di dalamnya terdapat 29 studi yang menguji hubungan self esteem dengan prestasi akademik, dianalisis. Lima belas jurnal penelitian menggunakan skala Global Self esteem satu faktor buatan Rosenberg dalam mengukur self esteem, dan satu jurnal penelitian menggunakan skala The Tennessee Self-Concept Scale (TSCS). Prestasi akademik dalam 16 jurnal penelitian yang didapatkan, dioperasionalkan sebagai nilai rata-rata akhir siswa dari tahun ajaran sebelumnya dan
\end{abstract}


nilai ujian siswa pada mata pelajaran tertentu. Hasil analisis menunjukkan bahwa terdapat korelasi yang signifikan antara self esteem dengan prestasi akademik. Koefisien korelasi populasi yang didapatkan tergolong rendah, yaitu sebesar 0,199. Lemahnya koefisien korelasi tidak dapat disimpulkan bahwa self esteem tidak mempengaruhi prestasi akademik. Namun, terdapat dua alternatif yang dapat menjelaskan lemahnya hubungan antara self esteem dengan prestasi akademik. Pertama, hubungan antara self esteem dengan prestasi akademik bersifat hubungan dua arah. Kedua, hubungan antara self esteem dengan prestasi akademik dimediasi oleh variabel efikasi diri akademik.

Kata Kunci : meta analisis, prestasi akademik,self esteem.

\section{Pendahuluan}

Pada usia anak, secara alami anakanak akan membandingkan dirinya dengan anak lain dalam capaian akademik, sebagai upaya untuk menilai kapasitas dirinya (Mulholand, 2008). Perbandingan ini sebenarnya ditujukan untuk menjawab pertanyaan fundamental yang biasanya muncul dalam diri anak-anak antara lain ; Siapa saya, Apakah saya dicintai, Apakah saya mampu mengatasinya (Chauhan, 2006). Jawaban anak terhadap pertanyaan ini akan membentuk penilaian anak terhadap diri, penilaian diri ini secara umum disebut self esteem (Chauhan, 20006). Self esteecm merupakan salah satu faktor utama dari bagaimana individu melihat dirinya atau konsep diri dan menjadi determinan penting dalam perilaku manusia (Afari, Ward, \& Lhine, 2012)

Selfesteem menentukan perkembangan mental seseorang secara keseluruhan (McClure, Tanski, Kinsbury, Gerrard, \& Sargent., 2010). Self esteem yang rendah berhubungan dengan kondisi psikologis, fisik dan konsekuensi sosial yang dapat mempengaruhi kesuksesan perkembangan masa transisi anak ke usia remaja (McClure, dkk., 2010), selain menjadi salah satu faktor yang penting bagi keberhasilan perkembangan anak, para ahli psikologi pendidikan mulai menjelaskan keterkaitan antara self esteem dengan prestasi akademik.

Beberapa penelitian berusaha meyakinkan bahwa self esteem mempengaruhi capaian akademik anak di sekolah (Harper \& Marshall, 1991). Penelitian paling lama tentang hubungan self esteem dengan prestasi akademik, yang berhasil peneliti telusuri adalah penelitian yang dilakukan Black (1974) yang meneliti keterkaitan antara usia, konsep diri (para ahli masih menyamakan antara konsep diri dengan self esteem) dengan prestasi akademik. Bachman dan O’Malley (1977) meneliti pengaruh self esteem terhadap proses pendidikan secara keseluruhan di sekolah, salah satunya prestasi akademik. Penelitian lain oleh Rogers, Smith, \& Coleman (1978) yang juga meneliti keterkaitan antara konsep diri dengan prestasi akademik. Hingga penelitian terbaru yang peneliti dapatkan, yaitu penelitian yang dilakukan oleh Zheng, Erickson, Kingston, dan Noonan (2014) yang meneliti tentang pengaruh self esteem terhadap prestasi belajar pada siswa yang memiliki kesulitan belajar. Banyak penelitian lain yang berusaha menjelaskan keterkaitan antara self esteem dengan prestasi akademik. Hanya berdasarkan pencarian melalui pada database ProQuest, Springerlink, dan EBSCO saja, peneliti bisa mendapatkan 35 jurnal yang meneliti keterkaitan antara self 
esteem dengan prestasi belajar.

Penelitian sebelumnya telah dilakukan untuk membuktikan keterkaitan antara self esteem dengan prestasi belajar, bahkan hingga saat ini, membuktikan bahwa tema ini masih menjadi perdebatan yang menarik. Beberapa ahli menyatakan terdapat korelasi antara self esteem dengan prestasi akademik (Lockett, \& Harrell., 2003; Colquhoun, dan Bourne., 2012). Ahli lainya menyatakan tidak ada korelasi antara kedua variabel, atau jika ada, korelasinya sangat kecil (Di Giunta., dkk., 2013 ; Zheng, dkk., 2014). Ahli lainnya menyatakan bahwa self esteem baru dapat mempengaruhi prestasi akademik, jika terdapat variable antara lain yang ikut diteliti (Afari, dkk., 2012). Bahkan beberapa ahli menyatakan, bukanlah self esteem yang mempengaruhi prestasi akademik, namun prestasi akademiklah yang mempengaruhi self esteem (Kohn, 1994). Perdebatan yang banyak mengenai keterkaitan antara self esteem dengan prestasi akademik, membuat peneliti tertarik untuk meneliti lebih lanjut keterkaitan antara self esteem dengan prestasi akademik.

Menurut Afari, Ward, dan Lhine, (2012), self esteem merupakan variabel yang mempengaruhi banyak perilaku manusia, maka self esteem akan sangat mungkin mempengaruhi perilaku manusia untuk mendapatkan prestasi yang baik di sekolah. Berdasarkan premis ini, peneliti berhipotesa, bahwa self esteem akan berkorelasi dengan prestasi akademik. Penelitian ini menggunakan metode meta analisis dengan mengintegrasikan hasil-hasil penelitian terdahulu untuk membuktikan hipotesa yang diajukan.

\section{Metode Penelitian}

Berdasarkan defenisi self esteem dan prestasi akademik, peneliti mencari literatur yang dianggap mendukung penelitian melalui berbagai sumber jurnal on-line. Sumber yang banyak digunakan sebagai alat penelusuran adalah domain perpustakaan online Universitas Gadjah Mada (UGM) dengan mencari jurnal pada database ProQuest, Springerlink, dan EBSCO. Kata kunci yang digunakan ketika pencarian jurnal dilakukan adalah self esteem, self concept, academic achivement dan academic peformance. Penelitian ini tidak menetapkan batasan tahun dalam menelusuri jurnal, berharap bahwa studi akan mejadi lebih luas jika berasal dari rentang tahun yang lebih luas. Jurnaljurnal yang ditemukan kemudian diseleksi berdasarkan atas kriteria inklusi jurnal yang telah ditetapkan sebelumnya.

Penelitian ini menentukan beberapa kriteria inklusi dalam menyeleksi jurnal penelitian yang diperoleh. Kriteria inklusi yang dalam penelitian ini adalah pertama, jurnal penelitian harus menggunakan self esteem sebagai variabel independen dan prestasi akademik sebagai variabel dependen. Beberapa padanan kata prestasi akademik dalam bahasa Inggris yang menjadi kriteria inklusi yaitu; academic achievement dan academic performance. Kedua, menyajikan informasi statistik yang diperlukan untuk melakukan analisis, antara lain ; jumlah sampel, nilai $r$, nilai $t$, atau nilai F.

Penelitian ini menemukan 35 jurnal penelitian yang menggunakan self esteem sebagai variable bebas dan prestasi akademik sebagai variabel tergantung, namun berdasarkan kriteria inklusi, peneliti hanya bisa menganalisa lebih lanjut, 16 jurnal penelitian. Enam belas jurnal penelitian terpilih, terdapat 29 studi yang menguji hubungan self esteem dengan prestasi akademik.

Selfesteem merupakan penilaian positif 
dan negatif terhadap diri (self). Terdapat dua teori pengukuran yang berkembang mengenai pengukuran self esteem. Teori dua faktor dan teori satu faktor. Penelitian ini memilih jurnal yang menggunakan teori satu faktor agar seragam. Teori satu faktor mendefenisikan self esteem sebagai sebuah kontinum antara penghargaan terhadap diri (self-worth) dan menilai diri rendah (selfdeprication). Lima belas jurnal penelitian menggunakan skala Global Self Esteem satu faktor buatan Rosenberg, dan satu jurnal penelitian menggunakan skala The Tennessee Self-Concept Scale (TSCS) dalam mengukur self esteem.

Prestasi akademik didefinisikan sebagai tingkat keberhasilan akademis individu. Prestasi akademik dalam 16 jurnal penelitian yang didapatkan, dioperasionalkan sebagai nilai rata-rata akhir siswa dari tahun ajaran sebelumnya dan nilai ujian siswa pada mata pelajaran tertentu. Skor prestasi akademik dari 16 jurnal penelitian yang didapatkan, berdasar penilaian guru terhadap kemampuan siswa pada mata pelajaran yang diajarkan, walaupun jenjang pendidikan pada jurnal penelitian yang didapatkan berbeda-beda, namun tetap memiliki esensi yang sama yaitu menggambarkan tingkat keberhasilan akademis individu.

Peneliti menggunakan metode meta-analisis, dimana analisis data yang akan dilakukan adalah Bare bones metaanalisis. Sebagaimana yang diuraikan oleh Hunter dan Schmidt (2004), dalam Bare bones meta-analisis dilakukan langkahlangkah berikut ; a) Menghitung rerata korelasi populasi, b) Menghitung varians, c) Menghitung varians kesalahan pengambilan sampel, d) Menghitung estimasi varians korelasi populasi, e) Menghitung interval kepercayaan, dan f) Menghitung dampak pengambilan sampel.

\section{Hasil dan Pembahasan}

Sampel penelitian yang akan dianalisis memiliki karakteristik seperti yang tercantum dalam Tabel 1 .

Tabel 1. Karakteristik Sampel Penelitian

\begin{tabular}{|c|c|c|c|c|c|}
\hline No & Tahun & Peneliti & $\begin{array}{l}\text { Studi } \\
\text { Ke }\end{array}$ & $\mathbf{N}$ & Karakteristik \\
\hline 1. & 2014 & Jenaabadi, $\mathrm{H}$. & 1 & 300 & Mahasiswa Master. Iran. \\
\hline 2. & 2012 & $\begin{array}{l}\text { Rosli, Y., Othman, H., Ishak, I., } \\
\text { Lubis, S. H., } \\
\text { Mohd. Saat, N. Z., dan Omar, B. }\end{array}$ & 1 & 220 & $\begin{array}{l}\text { Mahasiswa Sarjana, Tahun } \\
\text { Kedua. Malaysia. }\end{array}$ \\
\hline 3. & 2014 & $\begin{array}{l}\text { Soufi, S., Damirch, E. S., Sedghi, N., } \\
\text { dan Sabayan, B. }\end{array}$ & 1 & 417 & Siswa SMA. Iran. \\
\hline 4. & 2013 & $\begin{array}{l}\text { Hope, E. C., Chavous, T. M., Jagers, } \\
\text { R. J., dan Sellers, R. M. }\end{array}$ & 1 & 324 & $\begin{array}{l}\text { Mahasiswa Amerika } \\
\text { Keturunan Afrika. }\end{array}$ \\
\hline 5. & 2010 & Peixoto, F., dan Almeida, L. S. & 1 & 953 & Remaja. Portugal. \\
\hline 6. & 2014 & $\begin{array}{l}\text { Zheng, C., Erickson, A. G., Kingston, } \\
\text { N. M., dan. Noonan, P. M. }\end{array}$ & 1 & 560 & $\begin{array}{l}\text { Siswa yang mengalami } \\
\text { kesulitan belajar, usia } 13 \text { - } \\
16 \text { tahun. Amerika Serikat }\end{array}$ \\
\hline 7. & 2003 & $\begin{array}{l}\text { Lockett, C. T., dan } \\
\text { Harrell, J. P. }\end{array}$ & 1 & 128 & $\begin{array}{l}\text { Mahasiswa Amerika } \\
\text { Keturunan Afrika. }\end{array}$ \\
\hline
\end{tabular}


8. 2009 Peleg, O.

9. 2013 Zuffianò, A., Alessandri, G., Gerbino, M., Kanacri, B. P. L.,

Di Giunta, L., Milioni, M., dan Caprara, G. V.

10. 2013 Di Giunta, L., Alessandri, G., Gerbino, M., Kanacri, P. L., Zuffiano, A., dan Caprara, G. V.

11. 2013 Di Giunta, L., Alessandri, G., Gerbino, M., Kanacri, P. L., Zuffiano, A., dan Caprara, G. V.

12. 2013 Di Giunta, L., Alessandri, G., Gerbino, M., Kanacri, P. L., Zuffiano, A., dan Caprara, G. V.

13. 2013 Di Giunta, L., Alessandri, G., Gerbino, M., Kanacri, P. L., Zuffiano, A., dan Caprara, G. V.

14. 2012 Saadat, M., Ghasemzadeh, A., dan Soleimani, M.

15. 2013 Imran, $\mathrm{H}$.

16. 2011 Seabi, J.

17. 2011 Seabi, J.

18. 2011 Seabi, J.

19. 2011 Seabi, J.

20. 2011 Seabi, J.

21. 2012 Colquhoun, L. K., dan Bourne, P. A.

22. 1999 Bowles, T.

23. 1987 Demo, D. H., dan Keith, D. P.

24. 1987 Demo, D. H., dan Keith, D. P.

25. 1987 Demo, D. H., dan Keith, D. P.

26. 1987 Demo, D. H., dan Keith, D. P.

27. 1987 Demo, D. H., dan Keith, D. P.

28. 1987 Demo, D. H., dan Keith, D. P.

29. 1987 Demo, D. H., dan Keith, D. P.
102 Remaja laki-laki usia 1517 tahun, keturunan Arab. Israel

170 Siswa SMP, kelas 8. Italia

210 Siswa SMP, Perempuan. Italia.

1351 Remaja. Pakistan

1111 Mahasiswa. Afrika Selatan.

2111 Mahasiswa. Afrika Selatan.

3111 Mahasiswa. Afrika Selatan.

4111 Mahasiswa. Afrika Selatan.

5111 Mahasiswa. Afrika Selatan.

1120 Siswa SD. Jamaika

1180 Siswa usia 12-16 tahun. Australia

1298 Mahasiswa Amerika

2149 Mahasiswa Amerika berkulit hitam

3149 Mahasiswa Amerika berkulit putih

467 Mahasiswa Amerika lakilaki berkulit hitam

582 Mahasiswa Amerika perempuan berkulit hitam

675 Mahasiswa Amerika lakilaki berkulit putih

$7 \quad 74 \quad$ Mahasiswa Amerika perempuan berkulit putih 
Terdapat 26 studi dalam penelitian ini yang merupakan penelitian korelasi yang menghasilkan nilai $r$, satu penelitian perbandingan yang menghasilkan nilai $F$, dan dua penelitian perbandingan yang menghasilkan nilai $t$. Dilakukan transformasik terlebih dahulu nilai $F$ dan nilai $t$ menjadi nilai $d$ dan $r$.

Hasil transformasi nilai $\mathrm{F}$ dan $\mathrm{t}$ menjadi nilai $r$ dapat dilihat pada tabel 2 .

Tabel 2. Transformasi Nilai t Menjadi Nilai r

\begin{tabular}{|c|c|c|c|c|c|c|c|}
\hline No & Tahun & Peneliti & $\mathbf{N}$ & $\mathbf{F}$ & $T$ & d & $\mathbf{r}_{x y}$ \\
\hline 1. & 2014 & Jenaabadi, $\mathrm{H}$. & 300 & & & & 0,88 \\
\hline 2. & 2012 & $\begin{array}{l}\text { Rosli, Y., Othman, H., Ishak, I., Lubis, } \\
\text { S. H., } \\
\text { Mohd. Saat, N. Z., dan Omar, B. }\end{array}$ & 220 & & 8,864 & 1,2 & 0,51 \\
\hline 3. & 2014 & $\begin{array}{l}\text { Soufi, S., Damirch, E. S., Sedghi, N., } \\
\text { dan Sabayan, B. }\end{array}$ & 417 & & & & 0,259 \\
\hline 4. & 2013 & $\begin{array}{l}\text { Hope, E. C., Chavous, T. M., Jagers, } \\
\text { R. J., dan Sellers, R. M. }\end{array}$ & 324 & & & & 0,16 \\
\hline 5. & 2010 & Peixoto, F., dan Almeida, L. S. & 953 & 2,42 & 1,56 & 0,10 & 0,05 \\
\hline 6. & 2014 & $\begin{array}{l}\text { Zheng, C., Erickson, A. G., Kingston, } \\
\text { N. M., dan. Noonan, P. M. }\end{array}$ & 560 & & & & 0,079 \\
\hline 7. & 2003 & $\begin{array}{l}\text { Lockett, C. T., dan } \\
\text { Harrell, J. P. }\end{array}$ & 128 & & & & 0,315 \\
\hline 8. & 2009 & Peleg, O. & 102 & & & & 0,48 \\
\hline 9. & 2013 & $\begin{array}{l}\text { Zuffianò, A., Alessandri, G., Gerbino, } \\
\text { M., Kanacri, B. P. L., } \\
\text { Di Giunta, L., Milioni, M., dan } \\
\text { Caprara, G. V. }\end{array}$ & 170 & & & & 0,114 \\
\hline 10. & 2013 & $\begin{array}{l}\text { Di Giunta, L., Alessandri, G., Gerbino, } \\
\text { M., Kanacri, P. L., } \\
\text { Zuffiano, A., dan Caprara, G. V. }\end{array}$ & 78 & & & & 0,17 \\
\hline 11. & 2013 & $\begin{array}{l}\text { Di Giunta, L., Alessandri, G., Gerbino, } \\
\text { M., Kanacri, P. L., } \\
\text { Zuffiano, A., dan Caprara, G. V. }\end{array}$ & 133 & & & & 0,16 \\
\hline 12. & 2013 & $\begin{array}{l}\text { Di Giunta, L., Alessandri, G., Gerbino, } \\
\text { M., Kanacri, P. L., } \\
\text { Zuffiano, A., dan Caprara, G. V. }\end{array}$ & 191 & & & & 0,20 \\
\hline 13. & 2013 & $\begin{array}{l}\text { Di Giunta, L., Alessandri, G., Gerbino, } \\
\text { M., Kanacri, P. L., } \\
\text { Zuffiano, A., dan Caprara, G. V. }\end{array}$ & 210 & & & & 0,16 \\
\hline 14. & 2012 & $\begin{array}{l}\text { Saadat, M., Ghasemzadeh, A., dan } \\
\text { Soleimani, M. }\end{array}$ & 370 & & & & 0,05 \\
\hline 15. & 2013 & Imran, $\mathrm{H}$. & 351 & & 5,225 & 0,56 & 0,27 \\
\hline 16. & 2011 & Seabi, J. & 111 & & & & 0,24 \\
\hline 17. & 2011 & Seabi, J. & 111 & & & & 0,38 \\
\hline 18. & 2011 & Seabi, J. & 111 & & & & 0,29 \\
\hline 19. & 2011 & Seabi, J. & 111 & & & & 0,21 \\
\hline 20. & 2011 & Seabi, J. & 111 & & & & 0,29 \\
\hline 21. & 2012 & Colquhoun, L. K., dan Bourne, P. A. & 120 & & & & 0,611 \\
\hline
\end{tabular}


22. 1999 Bowles, T. 180

0,29

23. 1987 Demo, D. H., dan Keith, D. P. 298

0,00

24. 1987

Demo, D. H., dan Keith, D. P.

$-0,08$

25. 1987

Demo, D. H., dan Keith, D. P.

0,11

26. 1987

Demo, D. H., dan Keith, D. P.

0,02

27. 1987

Demo, D. H., dan Keith, D. P.

$-0,14$

28. 1987

Demo, D. H., dan Keith, D. P.

0,16

29. 1987

Demo, D. H., dan Keith, D. P.

0,24

Dua puluh sembilan studi telah memiliki nilai korelasi (r) setelah ditransformasi. Peneliti dapat melakukan langkah analisis berikutnya setelah mendapatkan nilai r.

Langkah selanjutnya peneliti melakukan koreksi kesalahan pengambilan sampel (Bare Bone Meta Analysis). Menggabungkan beberapa studi, kemudian mengestimasi rata-ratanya secara sederhana tidak mampu menggambarkan estimasi korelasi terintegrasi dari beberapa studi. Peneliti harus mengestimesi rerata yang dibobot untuk masing-masing korelasi kemudian dibagi dengan jumlah sampel dalam studi agar dapat menghasilkan estimasi korelasi terbaik yang mewakili korelasi dari beberapa studi yang dikumpulkan (Hunter \& Schmidt, 2014). Berikut hasil hasil perhitungan rerata korelasi dapat dilihat pada tabel 3 .

Tabel 3. Rerata Korelasi Populasi

\begin{tabular}{lclr}
\hline No Studi & $\mathbf{N}$ & \multicolumn{1}{c}{$\mathbf{r}_{\mathbf{i}}$} & $\mathbf{N}_{\mathbf{i}}{ }^{*} \mathbf{r}_{\mathbf{i}}$ \\
\hline 1. & 300 & 0,88 & 264,000 \\
2. & 220 & 0,51 & 112,200 \\
3. & 417 & 0,259 & 108,003 \\
4. & 324 & 0,16 & 51,840 \\
5. & 953 & 0,05 & 47,650 \\
6. & 560 & 0,079 & 44,240 \\
7. & 128 & 0,315 & 0,000 \\
8. & 102 & 0,48 & 61,440 \\
9. & 170 & 0,114 & 11,628 \\
10. & 78 & 0,17 & 28,900
\end{tabular}

\begin{tabular}{|c|c|c|c|}
\hline 11. & 133 & 0,16 & 12,480 \\
\hline 12. & 191 & 0,20 & 26,600 \\
\hline 13. & 210 & 0,16 & 30,560 \\
\hline 14. & 370 & 0,05 & 10,500 \\
\hline 15. & 351 & 0,27 & 99,900 \\
\hline 16. & 111 & 0,24 & 84,240 \\
\hline 17. & 111 & 0,38 & 42,180 \\
\hline 18. & 111 & 0,29 & 32,190 \\
\hline 19. & 111 & 0,21 & 23,310 \\
\hline 20. & 111 & 0,29 & 32,190 \\
\hline 21. & 120 & 0,611 & 67,821 \\
\hline 22. & 180 & 0,29 & 34,800 \\
\hline 23. & 298 & 0,00 & 0,000 \\
\hline 24. & 149 & $-0,08$ & $-23,840$ \\
\hline 25. & 149 & 0,11 & 16,390 \\
\hline 26. & 67 & 0,02 & 2,980 \\
\hline 27. & 82 & $-0,14$ & $-9,380$ \\
\hline 28. & 75 & 0,16 & 13,120 \\
\hline 29. & 74 & 0,24 & 18,000 \\
\hline & & 6256 & 1244 \\
\hline & & & 0,199 \\
\hline
\end{tabular}

Rerata korelasi populasi dengan dikoreksi oleh jumlah sampel didapatkan hasil 0,199. Nilai rerata korelasi populasi menjelaskan status hubungan antara kedua variable yang dikorelasikan pada tiap sampel penelitian, dengan mempertimbangkan jumlah sampel yang digunakan oleh tiap penelitian (Hunter \& Schmidt, 2014). Nilai rerata korelasi populasi sebesar 0,199 mengindikasikan korelasi antara self esteem dan prestasi akademik, lemah.

Tahap selanjutnya, peneliti melakukan perhitungan varians, menghitung varians 
kesalahan pengambilan sampel, menghitung varians korelasi populasi, menghitung interval kepercayaan, analisa terhadap dampak kesalahan pengambilan sampel dan analisis korelasi populasi. Hasil perhitungan varians dapat dilihat pada tabel 4.

Tabel 4. Varians

\begin{tabular}{lclrrr}
\hline No & $\mathbf{N}$ & $\mathbf{r}_{\mathbf{i}}$ & & & \\
\hline 1. & 300 & 0,88 & 0,681 & 0,464 & 139,194 \\
2. & 220 & 0,51 & 0,311 & 0,097 & 21,301 \\
3. & 417 & 0,259 & 0,060 & 0,004 & 1,509 \\
4. & 324 & 0,16 & $-0,039$ & 0,002 & 0,489 \\
5. & 953 & 0,05 & $-0,149$ & 0,022 & 21,112 \\
6. & 560 & 0,079 & $-0,120$ & 0,014 & 8,042 \\
7. & 128 & 0,315 & 0,116 & 0,013 & 0,000 \\
8. & 102 & 0,48 & 0,281 & 0,079 & 10,119 \\
9. & 170 & 0,114 & $-0,085$ & 0,007 & 0,734 \\
10. & 78 & 0,17 & $-0,029$ & 0,001 & 0,141 \\
11. & 133 & 0,16 & $-0,039$ & 0,002 & 0,118 \\
12. & 191 & 0,20 & 0,001 & 0,000 & 0,000 \\
13. & 210 & 0,16 & $-0,039$ & 0,002 & 0,288 \\
14. & 370 & 0,05 & $-0,149$ & 0,022 & 4,652 \\
15. & 351 & 0,27 & 0,071 & 0,005 & 1,874 \\
16. & 111 & 0,24 & 0,041 & 0,002 & 0,595 \\
17. & 111 & 0,38 & 0,181 & 0,033 & 3,643 \\
18. & 111 & 0,29 & 0,091 & 0,008 & 0,922 \\
19. & 111 & 0,21 & 0,011 & 0,000 & 0,014 \\
20. & 111 & 0,29 & 0,091 & 0,008 & 0,922 \\
21. & 120 & 0,611 & 0,412 & 0,170 & 18,856 \\
22. & 180 & 0,29 & 0,091 & 0,008 & 0,997 \\
23. & 298 & 0,00 & $-0,199$ & 0,040 & 7,117 \\
24. & 149 & $-0,08$ & $-0,279$ & 0,078 & 23,170 \\
25. & 149 & 0,11 & $-0,089$ & 0,008 & 1,176 \\
26. & 67 & 0,02 & $-0,179$ & 0,032 & 4,766 \\
27. & 82 & $-0,14$ & $-0,140$ & 0,020 & 1,313 \\
28. & 75 & 0,16 & $-0,039$ & 0,002 & 0,124 \\
29. & 74 & 0,24 & 0,041 & 0,002 & 0,127 \\
Total & 6256 & & & & 273 \\
Mean & 215,724 & & & & 9,425 \\
& & & & & \\
\hline & & & Varians antar & \\
& & & & studi & 0,0437 \\
\hline & & & & & \\
\hline
\end{tabular}

Berdasarkan tabel 4, diketahui varians hitung sebesar 0,0437 . Varians dalam studi meta analisis melambangkan bias atau error hasil korelasi dalam tiap sampel penelitian, dengan mempertimbangkan jumlah subyek penelitian yang digunakan dalam tiap peneltian (Hunter \& Schmidt, 2014). Nilai varians hitung sebesar 0,0437 mengindikasikan bahwa error yang terjadi tidak besar.

Peneliti menghitung varians kesalahan pengambilan sampel setelah menemukan nilai varians. Varians kesalahan pengambilan sampel sebesar 0,0043. Varians kesalahan pengambilan sampel merupakan salah satu bias dalam tiap penelitian yang merupakan artefak yang akan dipertimbangkan untuk mengambil keputusan korelasi antara dua variabel yang diteliti. Varians kesalahan sampel menggambarkan bias hasil penelitian yang diakibatkan oleh kesalahan dalam pengambilan sampel dalam tiap penelitian (Hunter \& Schmidt, 2014). Varians kesalahan pengambilan sampel sebesar 0,0043, mengindikasikan bias sangat kecil, dikarenakan jauh dari nilai satu.

Tahap selanjutnya, penelitimenghitung varians korelasi populasi. Varians korelasi populasi mengindiksikan penyimpangan hasil korelasi tiap penelitian dengan ratarata korelasi keseluruhan penelitian. Skor varians yang besar mengindikasikan semakin bervariasinya nilai korelasi dari tiap sampel penelitian yang diteliti. Skor varians korelasi sebesar 0,0394 mengindikasikan bahwa skor korelasi tiap penelitian dalam sampel yang diteliti tidak terlalu beragam.

Interval kepercayaan dapat dihitung dengan menggunakan persamaan berikut :

$$
\begin{aligned}
& 0,1991,96 \\
& 0,199 \pm 1,96 \times 0,20901 \\
& 0,199 \pm 0,4096 \\
& -0,211<<0,609
\end{aligned}
$$

Analisa terhadap dampak kesalahan pengambilan sampel menunjukkan 
angka 90,16 \% merupakan dampak kesalahan pengambilan sampel yang telah terspesifikasi. Hal ini bermakna bahwa nilai dampak kesalahan pengambilan sampel yang terhitung dalam penelitian ini cukup besar, sisanya sebesar 9,84\% merupakan dampak kesalahan pengambilan sampel yang belum terspesifikasi dalam penelitian ini.

Korelasi populasi () setelah dikoreksi oleh kesalahan sampel diestimasikan sebesar 0,199 , varians populasi sebesar 0,0437 . Interval kepercayaan 95\% dengan batas penerimaan antara $-0,211<<0,609$. Hasil ini menunjukkan bahwa hipotesis yang diajukan oleh peneliti diterima. Artinya, terdapat pengaruh antara self esteem dengan prestasi akademik.

Hasil analisis korelasi populasi sebesar 0,119 menunjukkan bahwa hubungan antara self esteem dengan prestasi akademik, lemah. Hasil ini membenarkan perdebatan yang terjadi diantara para ahli, dalam menentukan apakah self esteem memberikan pengaruh signifikan terhadap prestasi belajar. Hasil korelasi yang lemah, walaupun signifikan, belum cukup untuk meyakinkan bahwa self esteem memberikan pengaruh yang cukup (sufficient) terhadap prestasi akademik.

Berdasarkan hasil penelitian, yang menunjukkan korelasi yang lemah, membuat kita perlu berhati-hati dalam melihat hubungan antara self esteem dengan prestasi akademik. Pertama, apakah pola hubungan antara self esteem dengan prestasi akademik bersifat searah, atau berupa hubungan dua arah, dalam hubungan dua arah, bisa jadi self esteem mempengaruhi prestasi akademik, atau sebaliknya prestasi akademik mempengaruhi self esteem. Artinya, siswa bisa memiliki prestasi akademik tinggi akibat menilai dirinya secara positif, atau sebaliknya dikarenakan mendapatkan prestasi akademik yang baik membuat siswa lebih positif dalam menilai dirinya.
Pengaruh prestasi akademik terhadap self esteem telah mampu dibuktikan oleh Baumeister, Campbell, Krueger, \& Vohs, (2003) serta penelitian oleh Kohn (1994).

Kedua, kita bisa lebih berhati-hati dalam melihat apakah terdapat variabel lain yang ikut campur dalam pola hubungan antara self esteem dengan prestasi akademik. Peneliti cenderung lebih menerima penjelasan, yang menyatakan bahwa korelasi antara self esteem dengan prestasi akademik dimediasi oleh variabel lain. Hal ini telah dibuktikan oleh penelitian yang dilakukan oleh Di Giunta, dkk., (2013) dan Afari, dkk (2012). Kedua penelitian tersebut mampu membuktikan bahwa variabel efikasi diri akademik, signifikan menjadi variabel antara dalam pola hubungan self esteem dengan prestasi akademik, artinya penilaian positif siswa terhadap dirinya baru berkorelasi sangat kuat dengan prestasi akademiknya, jika siswa bersunguhsungguh dalam mengatur dirinya terkait dalam pemenuhan tugas-tugas akademik. Contoh yang dapat memberikan ilustrasi ini misalnya Ani yang menilai dirinya sebagai anak yang pintar (self esteem), kemudian mulai menerapkan aturan-aturan untuk mencapai prestasi akademik tinggi, seperti belajar mulai jam 8 malam hingga 9 malam (efikasi diri akademik), hal inilah yang akhirnya membuat Ani memiliki nilai yang bagus ketika ujian (prestasi akademik).

Kedua hal di atas, dapat menjadi alternatif dalam mencoba menjelaskan lemahnya hubungan antara self esteem dengan prestasi akademik, sedangkan alternatif lain tidak mendapatkan dukungan bukti yang kuat, misal bahwa studi tentang korelasi antara self esteem dengan prestasi akademik perlu lebih spesifik. Contoh yang dapat dilihat adalah prestasi akademik hanya diukur pada mata pelajaran tertentu, tidak memberikan solusi dalam 
memperkuat hubungan antara self esteem dengan prestasi akademik. Penelitian Seabi (2011) dan Crocker and Luhtanen (2003) membuktikan, walaupun prestasi akademik telah dispesifikkan pada mata pelajaran tertentu, korelasi antara self esteem dengan prestasi akademik tetap lemah, atau maksimal sedang.

\section{Simpulan}

Hasil analisis menunjukkan bahwa terdapat korelasi yang signifikan antara self esteem dengan prestasi akademik. Koefisien korelasi populasi yang didapatkan tergolong rendah, yaitu sebesar 0,199. Lemahnya koefisien korelasi tidak dapat disimpulkan bahwa self esteem tidak mempengaruhi prestasi akademik. Hal ini mengindikasikan bahwa hubungan antara self esteem dengan prestasi akademik bersifat hubungan dua arah dan hubungan antara self esteem dengan prestasi akademik dimediasi oleh variabel lain. Variabel yang terbukti signifikan sebagai variabel antara adalah variabel efikasi diri akademi (Di Giunta, dkk., 2013; Afari, dkk 2012).

\section{Daftar Pustaka}

Afari, E., Ward, G., dan Lhine, M. S., (2012). Global self esteem and self efficacy correlates: Relation of academic achievement and self esteem among emirati students. International Education Studies, 5, 2.

Bachman, J. S., \& O’Malley, P. M. (1977). Self esteem in young men: A longitudinal analysis of the impact of educational and occupational attainment. Journal of Personality and Social Psychology, 35, 365-380.

Black, F. W. (1974). Self-concept as related to achievement and age in learningdisabled children. Child Development, 45, 1137-1140.

Baumeister, R. F., Campbell, J.D., Krueger, J. I., \& Vohs, K. D. (2003). Does high self esteem cause better performance, interpersonal success, happiness, or healthier lifestyles?. Psychological Science in the Public Interest, 4, 1-44.

Bowles, T. (1999). Focusing on time orientation to explain adolescent self esteem, concept and academic achievement. Journal of Applied Health Behavior, 1, 2.

Chauhan, R. (2006). Relationship between academic self esteem and educational achievement of visually impaired suggestion for inclusion. Diunduh dari http://icevi.org/publications/icevi_ wc2006/09_inclusive_educational_ practices/Papers/wa_028_reema $\% 20$ chauhan.pdf

Colquhoun, L. K., \& Bourne, P. A., (2012). Self esteem and academic performance of 4th graders in two elementary schools in Kingston and St. Andrew, Jamaica. Asian Journal of Business Management, 4(1), 36-57.

Crocker, J., \& Luhtanen, R. K. (2003). Level of self esteem and contingencies of selfworth: Unique effects on academic, social, and financial problems in college students. Personality and Social Psychology Bulletin, 29(6), 701-712.

Demo, D. H., \& Keith, D. P. (1987). Academic achievement and self esteem among black and white college students. Journal of Social Psychology, 127, 345-355. 
Di Giunta, L., Alessandri, G., Gerbino, M., Kanacri, P. L., Zuffiano, A., \& Caprara, G. V. (2013). The determinants of scholastic achievement: The contribution of personality traits, self esteem, and academic self-efficacy. Learning and Individual Differences, 27, 102-108.

Harper, J. F., \& Marshall, E. (1991). Adolescents problems and their relationship to self esteem. Adolescene, 26, 799-807.

Hope, E. C., Chavous, T. M., Jagers, R. J., dan Sellers, R. M. (2013). Connecting self esteem and achievement: Diversity in academic identification and disidentification patterns among black college students. American Educational Research Journal, 50 (5), 1122-1151.

Hunter, J. E., \& Schmidt, F. L., (2004). Methods OfMeta-Analysis; Correcting Error and Bias in Research Findings. California; Sage Publications.

Imran, H. (2013). Self esteem manifestation in students with high and low academic achievement. Pakistan Journal of Psychology, 44 (2), 53-67.

Jenaabadi, H., (2014). Studying the relation between emotional intelligence and self esteem with academic achievement. Procedia - Social and Behavioral Sciences, 114, 203 - 206.

Kohn, A. (1994). The truth about self esteem. Phi Delta Kappan 83: 272-83

Lockett, C. T., \& Harrell, J. P., (2003). Racial identity, self esteem, and academic achievement: Too much interpretation, to little supporting data. Journal of Black Psychology, 29 (3), 325-336,
McClure, A. C., Tanski, S. E., Kingsbury, J., Gerrard, M., \& Sargent, J. D. (2010). Characteristics associated with low self esteem among US adolescents. Academic Pediatrics; 10, 4.

Mulholland, L., (2008). Nurturing self esteem in your child with special needs. The Exceptional Parent, 38, 12.

Peixoto, F., dan Almeida, L. S. (2010). Self concept, self esteem and academic achievement: strategies for maintaining self esteem in students experiencing academic failure. Eur $J$ Psychol Educ, 25, 157-175.

Peleg, O., (2009). Test anxiety, academic achievement, and self esteem among arab adolescents with and without learning disabilities. Learning Disability Quarterly, 32, 1.

Rogers, C. M,, Smith, M. D., \& Coleman, J. M. (1978). Social comparison in the classroom: The relationship between academic achievement and self-concept. Journal of Educational Psychology, 70, 50-57.

Rosli, Y., Othman, H., Ishak, I., Lubis, S. H., (2012). Self esteem and academic performance relationship amongst the second year undergraduate students of Universiti Kebangsaan Malaysia, Kuala Lumpur Campus. Procedia Social and Behavioral Sciences, 60, $582-589$.

Saadat, M., Ghasemzadeh, A., dan Soleimani, M. (2012). Self esteem in Iranian university students and its relationship with academic achievement. Procedia - Social and Behavioral Sciences, 31, $10-14$.

Seabi, J. (2011). Relating learning strategies, 
self-esteem, intellectual functioning with academic achievement among first-year engineering students. South African Journal of Psychology, 41(2), 239-249.

Soufi, S., Damirch, E. S., Sedghi, N., dan Sabayan, B., (2014). Development of structural model for prediction of academic achievement by global self esteem, academic self concept, self regulated learning strategies and autonomous academic motivation. Procedia - Social and Behavioral Sciences, 114, 26 - 35.

Zheng, C., Erickson, A. G., Kingston,
N. M., dan. Noonan, P. M. (2014). The relationship among selfdetermination, self-concept, and academic achievement for students with learning disabilities. Journal of Learning Disabilities, 47 (5). 462-474

Zuffianò, A., Alessandri, G., Gerbino, M., Kanacri, B. P. L., Di Giunta, L., Milioni, M., \& Caprara, G. V. (2013). Academic achievement: The unique contribution of self-efficacy beliefs in self-regulated learning beyond intelligence, personality traits, and self esteem. Learning and Individual Differences, 23, 158-162. 